\title{
In Vitro Antibacterial Activity and Minimum Inhibitory Concentration of Zinc Oxide and Nano-particle Zinc oxide Against Pathogenic Strains
}

\author{
Jehad M. Yousef, Enas N. Danial ${ }^{*}$ \\ Biochemistry Department, Sciences Faculty for Girls, King Abdulaziz University, P. O. Box 51459, Jeddah, 21453, Saudi Arabia
}

\begin{abstract}
In the emerging issue of increased multi-resistant properties in food borne pathogens, zinc oxide ( $\mathrm{ZnO})$ and nano-particle zinc oxide (nano- $\mathrm{ZnO}$ ) are being used increasingly as antimicrobial agents. Thus, the minimum inhibitory concentration (MIC) and minimum bactericidal concentration (MBC) of nano-ZnO towards pathogens microbes Bacillus subtilus NRRL B-543, Bacillus megaterium ATCC 25848, Staphylococcus aureus; NRRL B-313, Sarcina lutea ATCC27853, Escherichia coli; NRRL B-210, Pseudomonas aeruginosa NRRL B23 27853, Klebsiella pneumoniae ATCC 27736, proteus vulgaris NRRL B-123, Candida albicans NRRL Y-477 and Aspergillus niger NRRL-3 were examined in this study. The results obtained suggested that nano-Zno exhibit a good bacteriostatic effect but poor bactericidal effect towards all pathogens tested. Nano-ZnO can be a potential antimicrobial agent due to its low cost of production and high effectiveness in antimicrobial properties, which may find wide applications in various industries to address safety issues.
\end{abstract}

Keywords Nano Particles, Antimicrobial Activity Zinc Oxide Nano-Zinc Oxide

\section{Introduction}

Nanotechnology offers unique approaches to control a wide variety of biological and medical processes that occur at nanometer length and it is believed to have a successful impact on biology and medicine (1 -2). By controlling the structure precisely at nano scale dimensions, one can control and modify their surface layer for enhanced aqueous solubility, biocompatibility or bio-conjugation Nanoparticles exhibit attractive properties like high stability and the ability to modify their surface characteristics easily. The basic necessities for drug targeting are that the carrier should be capable of extended circulation in the blood stream; it must be small enough to gain access to target tissues and target cells (3). Nowadays, research efforts are being concentrated on integrating nano-particles with biology. It has been reported that antibiotics often disturb the bacterial flora of digestive tract which may develop multiple drug-resistant isolates, hence novel ways of formulating biocide materials is an upcoming field of attraction (4-7). For this reason, there is a need for the use of an agent which does not generate resistance and presents a good bactericidal property. The field of nanotechnology is one of the most active areas of research in modern materials science.

* Corresponding author:

enas_mahdy@yahoo.com (Enas N. Danial)

Published online at http://journal.sapub.org/health

Copyright (C) 2012 Scientific \& Academic Publishing. All Rights Reserved
Nano-particles exhibit completely new or improved properties based on specific characteristics such as size, distribution and morphology. New applications of nano-particles and nano-materials are emerging rapidly. Nano crystalline particles have found tremendous applications in the field of high sensitivity biomolecular detection and diagnostics, antimicrobials and therapeutics, Catalysis and microelectronics (8).

The commonly proposed pathogenic mechanisms initiated by nano particles (NPs) are dominated by inflammationdriven effects, including fibrosis, oxidative stress, and DNA damage, making inflammation a target for toxicological testing (9). Inflammation is a complex, concerted group of responses that, although defensive against infection, is harmful when induced chronically by environmental stimuli such as inhaled particles (10). The type, harmfulness, and outcome of inflammation vary depending on the nature of the stimulus initiating the inflammation; the affected tissue; the nature of the cellular exudates; its chronicity, severity, and potential to resolve; and the genetic susceptibility of the individual.

There are some reports (11) on the considerable antibacterial activity of $\mathrm{CaO}, \mathrm{MgO}$ and $\mathrm{ZnO}$, which is attributed to the generation of reactive oxygen species on the surface of these oxides. The advantage of using these inorganic oxides as antimicrobial agents is that they contain environmentally safe mineral elements essential to humans and exhibit strong activity even when administered in small amount. The activity is quantitatively evaluated by studying 
the growth medium caused by the bacterial metabolism (12). Many researchers have attempted to correlate the biological activity of inorganic antibacterial agents with the size of the constituent particles (13-14). The advantages of inorganic antibacterial materials over organic antibacterial materials are that the former show superior durability, less toxicity, greater selectivity and heat resistance. Nagarajan and Rajagopalan 2008 (15) reported that the activity was affected by particle size, which is controlled by processing parameters.

$\mathrm{ZnO}$ has recently achieved special attention regarding potential electronic application due to its unique optical, electrical and chemical properties (16).

The use of antimicrobial agents in them later on promoted to the emergence of resistance in micro-organism (17-18). Therefore, the resistant bacteria can certainly infect the humans via the food (19). The emergence and the development of antimicrobial resistance in pathogens with its scattering nature therefore turned into a global public health concern. Research has been intensively done in antibacterial material containing various natural and inorganic substances to overcome this problem (20). Among them, $\mathrm{ZnO}$ and nano- $\mathrm{ZnO}$ has known to have strong inhibitory and antibacterial effects as well as a broad spectrum of antimicrobial activities. The availability of a wide range of nanostructures makes $\mathrm{ZnO}$ an ideal material for nanoscale optoelectronics (21) and piezoelectric nanogenerators (22) as well as an efficient material for biotechnology (23). Furthermore, $\mathrm{ZnO}$ appears to be strongly resisted to microorganisms, and nano- $\mathrm{ZnO}$ are now widely used as antibacterial (24).

At present, $\mathrm{ZnO}$ and nano- $\mathrm{ZnO}$ have emerged as a viable treatment option for antimicrobial activities and then we determined the minimum inhibitory concentrations of the pathogenic strains which showed low resistant against $\mathrm{ZnO}$ and nano- $\mathrm{ZnO}$.

\section{Materials and Methods}

\subsection{Microorganisms}

The organisms used were: Gram positive bacteria namely Bacillus subtilus NRRL B-543, Bacillus megaterium ATCC 25848, Staphylococcus aureus; NRRL B-313 and Sarcina lutea ATCC27853, Gram negative bacteria Escherichia coli; NRRL B-210, Pseudomonas aeruginosa NRRL B23 27853, Klebsiella pneumoniae ATCC 27736 and proteus vulgaris NRRL B-123, pathogenic yeast Candida albicans NRRL Y-477 and fungi Aspergillus niger NRRL-3. These microorganisms were obtained from Natural Research center, Department of Chemistry of Natural and Microbial product Cairo Egypt.

\subsection{Antimicrobial Activity}

$\mathrm{ZnO}$ and nano- $\mathrm{ZnO}$ were tested in vitro for their antimicrobial activities against strains by the agar diffusion technique (25). The tested samples were dissolved in dimethyl sulfoxide (DMSO) to prepare chemicals of stock solutions of $20 \mu \mathrm{g} / \mathrm{ml}$. The pathogenic bacteria and fungi were maintained on nutrient agar and Czapek's-Dox agar media, respectively in Petri dishes with an inner diameter 9 $\mathrm{cm}$ to provide thin agar plates after solidification of thickness 3.4-3.5 mm. After solidification, hollows of 10 millimetre diameter wells were cut from the agar using a sterile cork-borer, and $0.1 \mathrm{ml}$ of each of the tested solutions were poured into the wells. The Petri dishes were incubated at $5-8^{\circ} \mathrm{C}$ for $2-3 \mathrm{~h}$ to permit good diffusion and then incubated for $24 \mathrm{~h}$ at $30^{\circ} \mathrm{C}$ in case of bacteria and $48 \mathrm{~h}$ at $28^{\circ} \mathrm{C}$ in case of yeast and fungi. After incubation the diameter of inhibition zone $(\mathrm{mm})$ was measured. amoxycillin and chloramphenicol, were purchased from Egyptian market and used in a concentration of $20 \mu \mathrm{g} / \mathrm{ml}$ as standard antibacterial and antifungal references.

\subsection{Minimum Inhibitory Concentration (MIC)}

The antimicrobial activities of the samples were evaluated through the determination of the minimum inhibitory concentration (MIC) by the micro dilution method in culture broth. For both the antibacterial and the antifungal assays, the compounds were dissolved in DMSO $(20 \mathrm{mg} / \mathrm{ml})$. Further dilutions were prepared at the required quantities of 20, 10, 51 and $0.5 \mu \mathrm{g} / \mathrm{ml}$ concentrations. The minimum inhibitory concentration (MIC) values were determined using the method of twofold serial dilutions (26). The Nutrient Broth, which contained tested samples and controls, were inoculated with approximately $5 \times 10^{5} \mathrm{cfu} / \mathrm{ml}$ of actively dividing bacterial and fungal cells or spores. The cultures were incubated for $24 \mathrm{~h}$ and $48 \mathrm{~h}$ at $30^{\circ} \mathrm{C}$ on a metabolic rotary shaker (220 rev/min), and the growth was monitored visually and spectrophotometerically (at $540 \mathrm{~nm}$ ). In order to ensure that the solvent had no effect on bacterial growth, a control test was also performed containing inoculated broth supplemented with only DMSO at the same dilutions used in our experiments and found inactive in culture medium.

The MIC was defined as the lowest concentration required to arrest the growth of the bacteria at the end of $24 \mathrm{~h}$ of incubation. The MBC was determined by sub culturing a 0 . $1-\mathrm{ml}$ volume of the medium drawn from the culture tubes after $48 \mathrm{~h}$ on Nutrient Agar and incubated further for bacterial growth. The growth was scored for relative numbers of the bacterial colonies. The lowest concentration of the antimicrobial agent causing negative growth (fewer than three colonies) was considered the MBC. Since the MIC and $\mathrm{MBC}$ were virtually the same, we generally reported only the $\mathrm{MBC}$ in the results.

\section{Results and Desiccations}

A wide variety of synthetic compounds exert antibacterial effect, but just some of them can be used as biocides to develop drugs or coatings. The primary impediment for their use is their toxicity compared with their bactericidal effect; 
some of them are so toxic for eukaryotic cells that cannot be proposed as antibiotics. Among these materials, $\mathrm{ZnO}$ and nano- $\mathrm{ZnO}$ compounds raise as potent antimicrobial agents. The advantage of using these inorganic oxides as antimicrobial agents is that they contain environmentally safe mineral elements essential to humans and exhibit strong activity even when administered in small amount In order to study $\mathrm{ZnO}$ and nano- $\mathrm{ZnO}$ as novel antimicrobial agents. The antimicrobial activity of $\mathrm{ZnO}$ and nano- $\mathrm{ZnO}$ were determined against Bacillus subtilus NRRL B-543, Bacillus megaterium ATCC 25848, Staphylococcus aureus; NRRL B-313, Sarcina lutea ATCC27853, Escherichia coli; NRRL B-210, Pseudomonas aeruginosa NRRL B23 27853, Klebsiella pneumoniae ATCC 27736, proteus vulgaris NRRL B-123, Candida albicans NRRL Y-477 and Aspergillus niger NRRL-3 as a pathogenic strains.

\subsection{Agar Diffusion Technique}

Antimicrobial activities of $\mathrm{ZnO}$ and nano- $\mathrm{ZnO}$ tested against pathogenic microorganisms using agar diffusion technique. The results represented in Fig (1) showed that the best zone of inhibition against Bacillus subtilus $(24 \mathrm{~mm})$, Escherichia coli $(24 \mathrm{~mm})$ Staphylococcus aureus $(22 \mathrm{~mm})$ and Pseudomonas aeruginosa $(22 \mathrm{~mm})$ for oxide zinc nano-partials. The date also refer that $\mathrm{ZnO}$ has moderated effect on Bacillus megaterium (20mm), Sarcina lutea $(18 \mathrm{~mm})$, Candida albicans $(18 \mathrm{~mm})$, Klebsiella pneumoniae $(16 \mathrm{~mm})$ proteus vulgaris $(14 \mathrm{~mm})$, and Aspergillus niger $(14 \mathrm{~mm})$.

On the other hand the uses of $\mathrm{ZnO}$ appeared the lowest effect on all tested microorganisms as shown in Fig (1). The antimicrobial ability of nano- $\mathrm{ZnO}$ might be referred to their small size which is 250 times smaller than a bacterium. This makes them easier to adhere with the cell wall of the microorganisms causing its destruction and leads to the death of the cell. Also, metal nano-particles are harmful to bacteria and fungi (26). Nano-ZnO stimulate biofilm production and aggregate within this bio-film. They bind closely to the surface of microorganisms causing visible damage to the cells, and demonstrating good self assembling ability. Nano-ZnO possess well-developed surface chemistry, chemical stability which make them easier to interact with the microorganisms (27). Also, the particles interact with the building elements of the outer membrane and might cause structural changes, degradation and finally cell death.

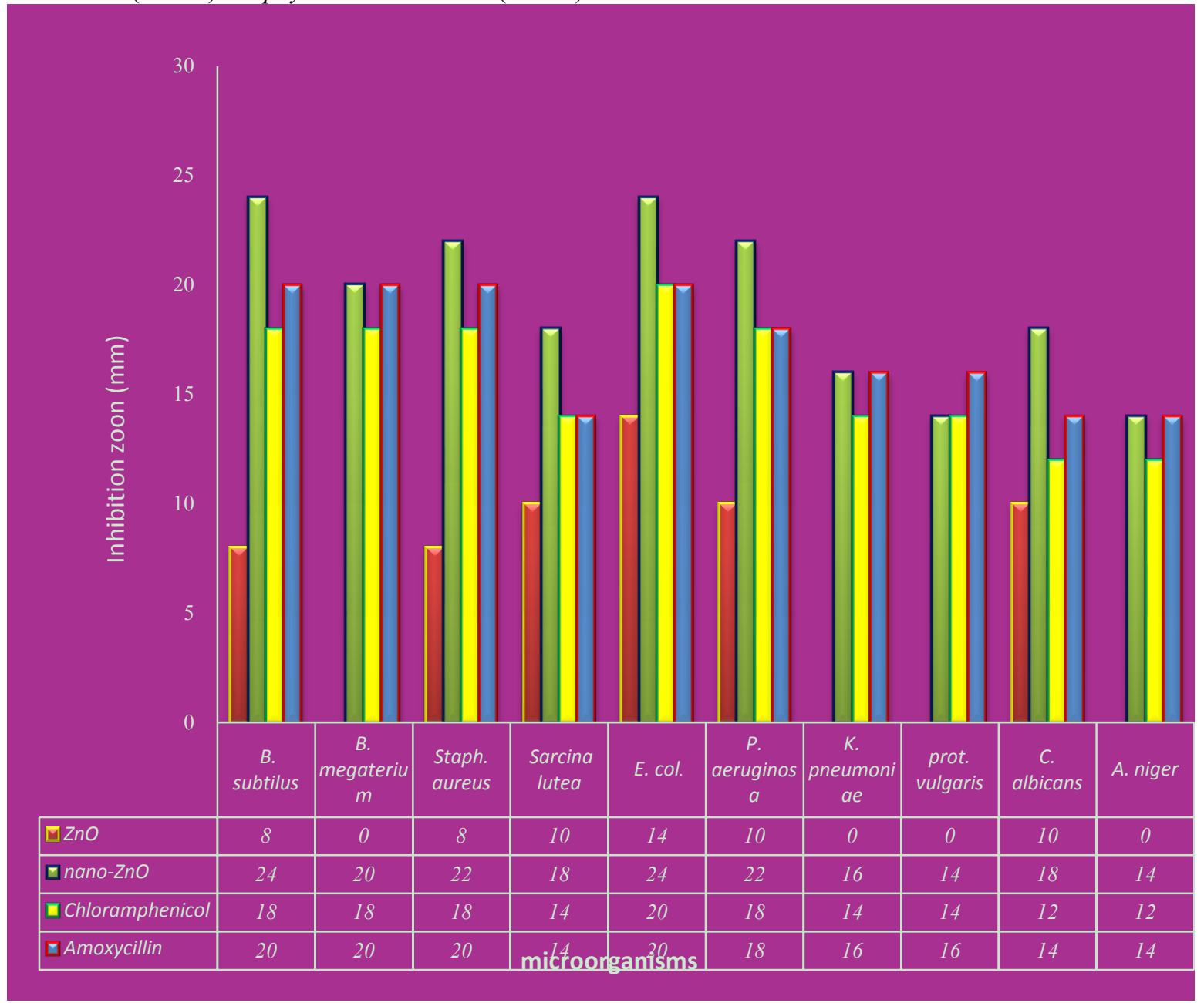

Figure 1. Antimicrobial activity of $\mathrm{ZnO}$ and nano $-\mathrm{ZnO}$ against pathogenic microorganisms

The effective of $\mathrm{ZnO}$ and nano- $\mathrm{ZnO}$ can be explained on the basis of the oxygen species released on the surface of 
$\mathrm{ZnO}$, which cause fatal damage to microorganisms (28). The generation of highly reactive species such as $\mathrm{OH}^{-}, \mathrm{H}_{2} \mathrm{O}_{2}$ andO ${ }_{2}{ }^{2-}$ is explained as follows. Since $\mathrm{ZnO}$ with defects can be activated by both UV and visible light, electron-hole pairs $\left(\mathrm{e}^{-} \mathrm{h}^{+}\right)$can be created. The holes split $\mathrm{H}_{2} \mathrm{O}$ molecules (from the suspension of $\mathrm{ZnO}$ ) into $\mathrm{OH}^{-}$and $\mathrm{H}+$. Dissolved oxygen molecules are transformed to superoxide radical anions $\left(\mathrm{O}^{-}{ }_{2}\right)$, which in turn react with $\mathrm{H}^{+}$to generate $\left(\mathrm{HO}_{2}{ }^{\circ}\right)$ radicals, which upon subsequent collision with electrons produce hydrogen peroxide anions $\left(\mathrm{HO}_{2}{ }^{-}\right)$. They then react with hydrogen ions to produce molecules of $\mathrm{H}_{2} \mathrm{O}_{2}$. The generated $\mathrm{H}_{2} \mathrm{O}_{2}$ can penetrate the cell membrane and kill the bacteria (29)

$$
\begin{gathered}
\mathrm{ZnO}+\mathrm{hv} \rightarrow \mathrm{e}^{-}+\mathrm{h}^{+} ; \mathrm{h}^{+}+\mathrm{H}_{2} \mathrm{O} \rightarrow{ }^{\circ} \mathrm{OH}+\mathrm{H}^{+} . \\
\mathrm{e}^{-}+\mathrm{O}_{2} \rightarrow \mathrm{O}^{-} ;{ }^{\circ} \mathrm{O}_{2}+\mathrm{H}^{+} \rightarrow \mathrm{HO}_{2}^{\circ} \\
\mathrm{HO}_{2}^{*}+\mathrm{H}^{+}+\mathrm{e}^{-} \rightarrow \mathrm{H}_{2} \mathrm{O}_{2}
\end{gathered}
$$

Since, the hydroxyl radicals and superoxide are negatively charged particles, they cannot penetrate into the cell membrane and must remain in direct contact with the outer surface of the bacteria cell of the bacteria; however, $\mathrm{H}_{2} \mathrm{O}_{2}$ canpenetrateinto the cell (30).

Concerning, the effect of the amoxycillin as antibiotic or chloromphenicol in combination $\mathrm{ZnO}$ and nano- $\mathrm{ZnO}$ were studied. It indicated that the best results were against Escherichia coli with zone of inhibition equal (20 and $20 \mathrm{~mm}$ ), respectively followed by Bacillus megaterium (20 and $18 \mathrm{~mm})$, Bacillus subtilus $(20$ and $18 \mathrm{~mm})$, Staphylococcus aureus (20 and $18 \mathrm{~mm})$, Pseudomonas aeruginosa (18 and $18 \mathrm{~mm}$ ), Klebsiella pneumoniae (16 and $14 \mathrm{~mm})$, proteus vulgaris (16 and $14 \mathrm{~mm})$, Sarcina lutea, (14 and $14 \mathrm{~mm}$ ) Candida albicans (14 and 12 and Aspergillus niger (14 and $12 \mathrm{~mm}$ ), as shown in Figure (1). This results will be agreement with the results obtains by (31).

\subsection{Minimum Inhibitory Concentration (MIC)}

Table 1. Antimicrobial activity (MIC values in $\mu \mathrm{g} / \mathrm{mL}$ ) nano- $\mathrm{ZnO}$ towards pathogenic microorganismes

\begin{tabular}{|c|c|c|}
\hline $\begin{array}{c}\text { Type of } \\
\text { pathogenic }\end{array}$ & microorganisms & $\begin{array}{c}\text { Minimum inhibitory } \\
\text { concentration in } \boldsymbol{\mu g} / \mathbf{m L}\end{array}$ \\
\hline \multirow{3}{*}{$\begin{array}{c}\text { Gram }^{+} \text {positive } \\
\text { bacteria }\end{array}$} & B. subtilus & $>\mathbf{5}$ \\
\cline { 2 - 3 } & B. megaterium & $\mathbf{5}$ \\
\cline { 2 - 3 } & Staph. aureus & $>\mathbf{1}$ \\
\cline { 2 - 3 } & Sarcina lutea & $>\mathbf{5}$ \\
\hline \multirow{3}{*}{$\begin{array}{c}\text { Gram }^{-} \\
\text {positive bacteria }\end{array}$} & E. col. & $>\mathbf{0 . 5}$ \\
\cline { 2 - 3 } & P. aeruginosa & $\mathbf{0 . 5}$ \\
\cline { 2 - 3 } & K. pneumoniae & $>\mathbf{5}$ \\
\cline { 2 - 3 } Fungal species & prot. vulgaris & $>\mathbf{5}$ \\
\cline { 2 - 3 } & C. albicans & $>\mathbf{1 0}$ \\
\hline \multirow{2}{*}{} & A. niger & $>\mathbf{1 0}$ \\
\hline
\end{tabular}

In our study, the relative antimicrobial activity of nano-ZnO suspensions against Pathogenic microorganisms were studied qualitatively in aqueous nutrient broth quantitatively in terms of the MIC and MBC. The MIC of the agent is the concentration at which the solution becomes turbid (32). Here, five nano- $\mathrm{ZnO}$ suspensions with different concentrations were tested, in the range of 0.5 to $20 \mu \mathrm{g}$ and the results are given in table (1). The data shows that all tested microorganisms were completely inhibited at the concentration of 0.5 to $20 \mu \mathrm{g} / \mathrm{ml}$ of nano- $\mathrm{ZnO}$. The nano- $\mathrm{ZnO}$ solution at the concentration of $10 \mu \mathrm{g} / \mathrm{ml}$ of nano- $\mathrm{ZnO}$ showed inhibition kinetics against all test organisms but no significant antibacterial activity was observed at concentrations less than $0.5 \mu \mathrm{g} / \mathrm{ml}$ of nano- $\mathrm{ZnO}$

The MIC of nano-ZnO against Escherichia coli; and Pseudomonas aeruginosa, were the best affect at the both strains $(4 \mu \mathrm{g} / \mathrm{ml})$, followed by Staphylococcus aureus (1 $\mu \mathrm{g} / \mathrm{ml})$. The moderated effect had been showed By Bacillus subtilus, Bacillus megaterium, Sarcina lutea, Klebsiella pneumonia and proteus vulgaris $(5 \mu \mathrm{g} / \mathrm{ml})$, Once nano- $\mathrm{ZnO}$ kills/captures the cell membrane, the nano-ZnO presumably remain tightly adsorbed on the surface of the leftover/dead bacteria preventing further antibacterial action. However, nano- $\mathrm{ZnO}$ continue to release peroxides into the medium even after the surface of the dead bacteria are completely covered by nano- $\mathrm{ZnO}$, so it showing high bactericidal efficacy (15). But the lowes effect has been recorded by Candida albicans NRRL Y-477 and Aspergillus niger (10 $\mu \mathrm{g} / \mathrm{ml}$ ), Fungicidal activity of nano- $\mathrm{ZnO}$ was due to destroying cell membrane integrity (25).

MIC results obtained in our study resembled those reported by Nawaz (33). The reported results of MIC are higher than those obtained by us in the present study, which suggests that, the antimicrobial activity of $\mathrm{ZnO}$ and nano-ZnO may be influenced by preparation method as well as by particle size. The difference in MIC results against the test microorganisms might be due to the strains used. Thus, we can conclude from the results of this study that the nano- $\mathrm{ZnO}$ inhibited the growth and multiplication of all the tested microorganisms.

\section{REFERENCES}

[1] West J.L. and Halas N.J. (2000): Applications of nanotechnology to biotechnology. Curr. Opin. Biotech. 11: 215 .

[2] Zandonella C. (2003): Cell nanotechnology: The tiny toolkit. Nature; 423: 10-12.

[3] Tom R.T., Suryanarayanan V., Ganapati Reddy P. Baskaran, S. and Pradeep T. (2004): Ciprofloxacin-Protected Gold Nanoparticles. Langmuir; 20:1909-1914.

[4] Jarvinen H., Tenovuo, J. and Huovinen P. (1993): In vitro susceptibility of Streptococcus mutans to chlorhexidine and six other antimicrobial agents. Antimicrob Agents Chemother; 37(5): 1158-1159

[5] Concannon S.P., Crowe T.D., Abercrombie J.J., Molina, C.M., Hou, P. and Sukumaran D.K. (2003): Susceptibility of oral bacteria to an antimicrobial decapeptide. J Med. Microbiol. 52:1083-1093.

[6] Altman H., Steinberg D., Porat Y., Mor A., Fridman D. and Friedman M. (2006): In vitro assessment of antimicrobial peptides. J Antimicrob Chemother; 58:198-201. 
[7] Daglia M., Papetti A., Grisoli P., Aceti C., Dacarro, C. and Gazzani G. (2007): Antibacterial activity of red and white wine against oral streptococci. J. Agric. Food Chem. 55: $5038-5042$.

[8] Jain D., Kumar Daima H., Kachhwaha S. and Kothari S. L.(2009): Synthesis of Plant-mediated silver nanoparticles using papaya fruit extract and evaluation of their antimicrobial activities. A. Digest Journal of Nanomaterials and Biostructures: 4, $557-563$.

[9] Lu S, Duffin R, Poland C, Daly P, Murphy F, Drost E, MacNee M, Stone V and Donaldson K. (2009). Efficacy of simple short-term in vitro assays for predicting the potential of metal oxide nanoparticles to cause pulmonary inflammation. Environ Health Perspect 117:241-247.

[10] Donaldson K, Aitken R, Tran L, Stone V, Duffin R, Forrest G and Alexander A. (2006): Carbon nanotubes: a review of their properties in relation to pulmonary toxicology and workplace safety. Toxicol Sci 92(1):5-22.

[11] Sawai J. and Yoshikawa T. (2004): Quantitative Evaluation of Antifungal Activity of Metallic Oxide Powders (MgO, $\mathrm{CaO}$ and $\mathrm{ZnO}$ ) By an Indirect Conductimetric Assay, J. Appl. Microbiol. 96, 803.

[12] Sawai J., Doi R., Maekawa Y., Yoshikawa T., and Kojima H. ( 2002): Short Communication Indirect Conductimetric Assay of Antibacterial Activities," J. Ind. Microbiol. Biotech. 29: 296.

[13] Stoimenov P. K., Klinger R.L., Marchin G.L, and Klabunde K.J, (2002): Metal Oxide Nanoparticles as Bactericidal Agents, Langmuir 18, 6679.

[14] Brayner R., Ferrari-lliou R., Brivois N., Djediat S., Benedetti M. F., and Fievet F. (2006): Toxicological Effect of $\mathrm{ZnO}$ Nanoparticles Based on Bacteria," Nano Lett. 6: 866

[15] Nagarajan P. and Rajagopalan V. (2008): Enhanced bioactivity of $\mathrm{ZnO}$ nano-particles - an antimicrobial study. Environ. Sci. Technol. 9 (035004), 7-15

[16] Baxter J. B. and Aydil E.S. ( 2005): Nanowire based dye sensitized solar cells. Appl. Phys. Lett. 86, 53114, 2005.

[17] Asai T., Kojima A., Harada K., Ishihara K., Takahashi T. and Tamura Y. (2005): Correlation between the usage volume of veterinary therapeutic antimicrobials and resistance in Escherichia coli isolated from the feces of food-producing animals in Japan. Journal of Infectious Diseases 58: 369-372

[18] Olofsson S.K. (2006): Relation between drug exposure and selection of antibiotic resistant bacteria. Uppsala, Sweden: Uppsala University, Faculty of Medicine, Dissertation

[19] Phillips I., Casewe M., Cox T., Groot D.B., Friis C., Jones R., Nightingale C., Preston R. and Waddell J. (2004): Does the use of antimicrobials in food animals pose a risk to human health? Journal of Antimicrobial Chemotherapy 53, 28-52.

[20] Kim J.S., Kuk E., Yu K.N., Kim J.H., Park S.J., Lee H.J., Kim S.H., Park Y.K., Park Y.H., Hwang C.Y., Kim Y.K., Lee Y.S., Jeong D.H. and Cho M.H.(2007): Antimicrobial effects of silver nanoparticles. Journal of Nanomedicine 3(1): 95-101.

[21] Sawai J., Igarashi H., Hashimoto A., Kokugan,c T. and Shimizu M. (1996): Antibacterial Characteristics of Magnesium Oxide Powder. J. Chem. Eng. Japan 29, 556

[22] Wang Z.L. (2004): Functional Oxides Nanobelts Materials, Properties and Potential Applications in Nanosystems and Biotechnology, Annu. Rev. Phys. Chem. 55(159): 1656-1662

[23] Song J., Zhou J., and Wang Z.L. (2006): Piezoelectric and Semi conducting Coupled Power Generating Process of a Single $\mathrm{ZnO}$ Belt/Wire. A Technology for Harvesting Electricity from the Environment. Nano, Lett. 6: 1656.

[24] Huang M.H., Mao S., Feick H., Yan H.Q., Wu Y., Kind H., Weber E., Russo R, and Yang P.(2001): ZnO Microrods Photodeposited with $\mathrm{Au}-\mathrm{Ag}$ Nanoparticles: Synthesis, Characterization and Application, In Sers. Science 292: 1897

[25] Perez C., Pauli M. and Bazevque P. (1990) An antibiotic assay by the agar well diffusion method. Acta Biologiae et Medicine Experimentalis 15, 113-115

[26] Chwalibog A., Sawosz E., Hotowy A., Szeliga J., Mitura S., Mitura K., Grodzik M., Orlowski P. and Sokolowska, A. (2010): Visualization of interaction between inorganic nano-particles and bacteria or fungi. International Journal of Nanomedicine; 5, 1085-1094.

[27] Nirmala G. A. and Pandian K. (2007): Antibacterial efficacy of aminoglycosidic antibiotics protected gold nano-particles a brief study. Colloids and Surfaces a: Physicochem. Eng. Aspects 297: 63-70.

[28] Sunada K., Kikuchi Y., Hashimoto K. and Fujshima A. (1998): Bactericidal and detoxification effects of $\mathrm{TiO} 2$ thin film photocatalysts. Environ.Sci.Technol. 32 (5), 726-728.

[29] Fang M., Chen J. H., Xu X. L., Yang P. H. and Hildebr H. F. (2006): Antibacterial activities of inorganic agents on six bacteria associated with oral infections by two susceptibility tests Int. J. Antimicrob. Agents 27, 513-517

[30] Blake M. D., Maness P., Huang Z., Wolfrum E. J., Huang J. and Jacoby W. A. (1999): Application of the photo catalytic chemistry of titanium dioxide to disinfection and the killing of cancer cells. Sep. Purif. Methods 28 (1)1-50

[31] Zawrah M. F. and Abd El-Moez S. I. (2011): Antimicrobial Activities of Gold Nanoparticles against Major Foodborne Pathogens Life Science Journal. 8(4) 37-44

[32] Avanzato C. P., Folliri J. M. and Banerjee I. A. (2009): Bio mimetic Synthesis and Antibacterial Characteristics of Magnesium Oxide-Germanium dioxide Nano-composite Powders Journal of composite materials, 43 (8), 897-910

[33] Nawaz H. R., Solangi B. A., Zehra B. and Nadeem U. (2011): Preparation of Nano Zinc Oxide and its Application in Leather as a Retaining and Antibacterial Agent. Canadian Journal on Scientific and Industrial Research. 2 (4): 164-170 